\title{
Bibliometric Analysis of Psychological Literature Based on Web of Science Data
}

\author{
Chao Cui \\ Foreign Language College \\ Inner Mongolia Agricultural University \\ Hohhot, Inner Mongolia, China \\ victorcui1983@yeah.net
}

\begin{abstract}
Based on the bibliometric method, this paper analyzes an overall situation of 5337 psychological literature academic papers in the Web of Science database between the year of 1992 and 2018, focusing on indicators as the periodicals, authors, institutions, funds, popularity. On this basis, the status quo and problems of the research field are evaluated and classified, indicating that the peak year is 2017 , the most popular aspect is psychiatry, the most frequent research genre is article, the top research achievements in quantity goes to the US, which owns the most intensive academic cooperation, the Ohio State University comes to the top in influence among institutions, Psychological Bulletin is the leading periodical, MacCallum, RC is the most being quoted author, the key words of the research object are stress, cancer, nursing, new research objects include women, randomized controlled-trial, and prevalence. Based on those inferences, three tendencies can be revealed: In 2017, the psychiatry enjoys the top importance, female metal stress, cancer and stress related physical health issues and nursing can be the most popular topics in the US.
\end{abstract}

Keywords—psychological literature; bibliometric analysis; knowledge graph

\section{INTRODUCTION}

Literary activities include two links of creation and acceptance, and whether it is creation or acceptance is the main psychological activity of the subject. In particular, the creative subject is in the process of creation not only to unfold imaginary fiction, but also to figure out the psychology of the characters in the works, so as to accurately describe the characters' appearance and behavior. Bibliometric is statistical study of written materials, such as published journal articles and books.

Understanding the state of literary research area is of the highest importance for relating researchers. This paper provides quantitative results of academic psychological literature for figuring out research trend. In this study, web of science publication search engines is used, and their search results are derived and analyzed. Just like statistics, there is popular saying "rubbish in, rubbish out". Artificial intelligence and powerful, people still need to continue to use big data to feed.

\section{DATA SOURCES AND RESEARCH METHODS}

\section{A. Data sources}

This paper takes Web of Science as the data source, and takes psychological analysis in literature as the research object Excluding the call for non-academic papers, 5337 articles are retained as research samples.

\section{B. Research methods}

The research method adopted in this paper is based on three empirical statistical laws. For example, the law of Lotka (1926) is characterized by the distribution of the authors of scientific and Technological Literature (1926); the Zipf's law of word frequency distribution in the literature (1948) is characterized, and the Brad Ford's Law (1934), which is distributed in a periodical, is determined. This paper uses WOS website's literature analysis tool and https://bibliometric.com/ website to achieve the purpose of bibliometric.

\section{LITERATURE DISTRIBUTION AND CORE RESEARCH STRENGTH} ANALYSIS

\section{A. Analysis of the total amount of literature}

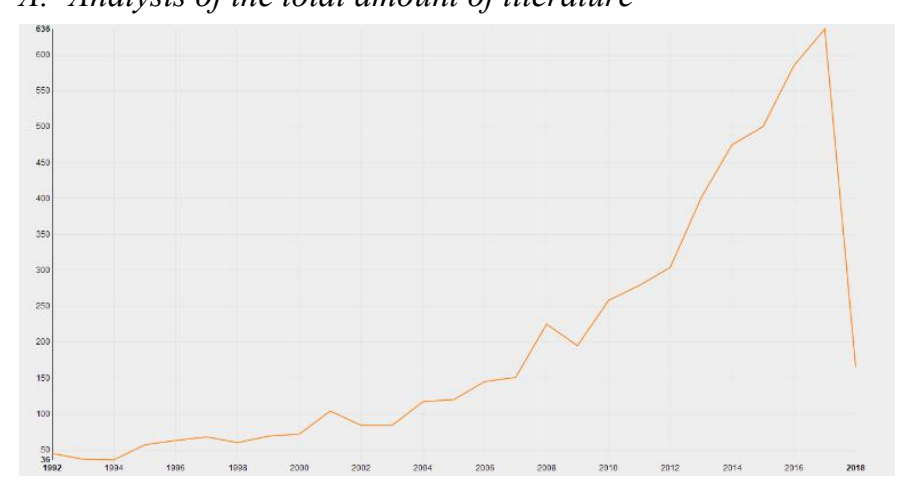

Fig. 1. Changes in number of articles over the years

To some extent, the change of the number of documents can reflect the theoretical level and speed of the discipline. The research started from 1992 to 2018, and formed a research peak. It can be divided into three periods: germination period (from 1992 to 2002), exploration period (from 2003 to 2009) and development period (from 2010 to 2018) 

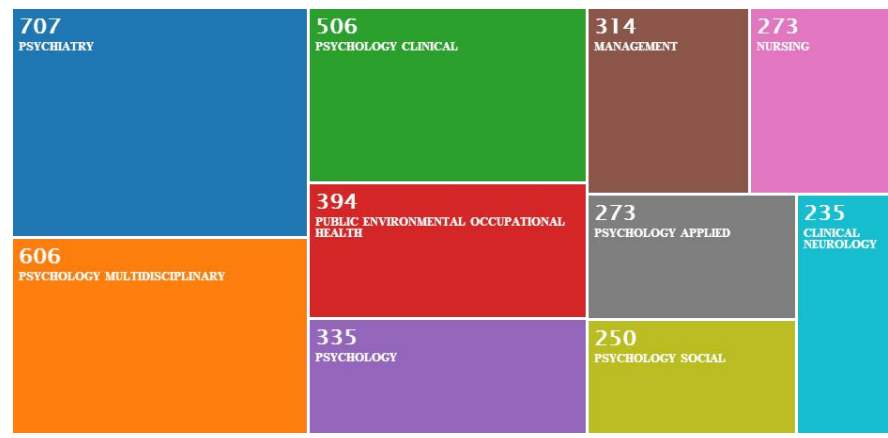

Fig. 2. Research direction

In the literature works concerning psychoanalysis, the research direction is focused on psychiatry, psychology multidisciplinary and psychology clinical academic research.

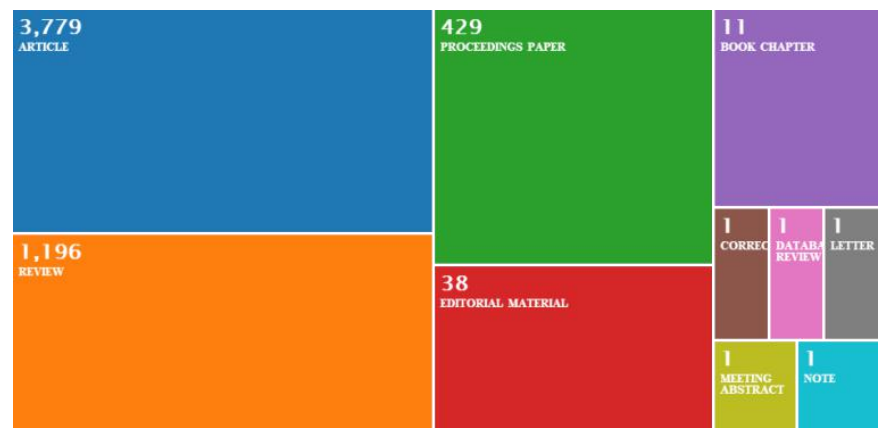

Fig. 3. Research genres

The research genres mainly contain article, review and proceedings paper.

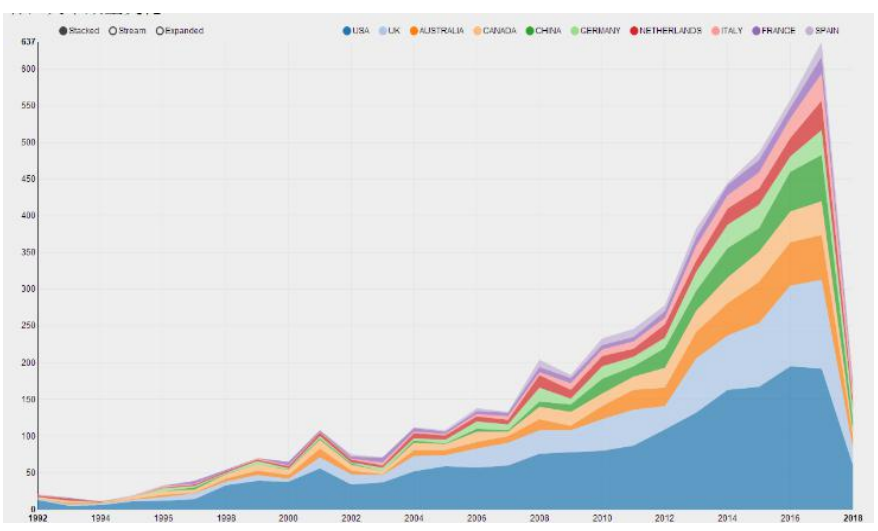

Fig. 4. Changes in the number of articles in various countries over the years

From Fig. 5, according to the analysis results of separate countries, American research achievements are on the top, followed by UK and Australia. It can be seen that the main research results are concentrated in the United States, UK and Australia.

\section{B. Analysis of cooperative relationship}

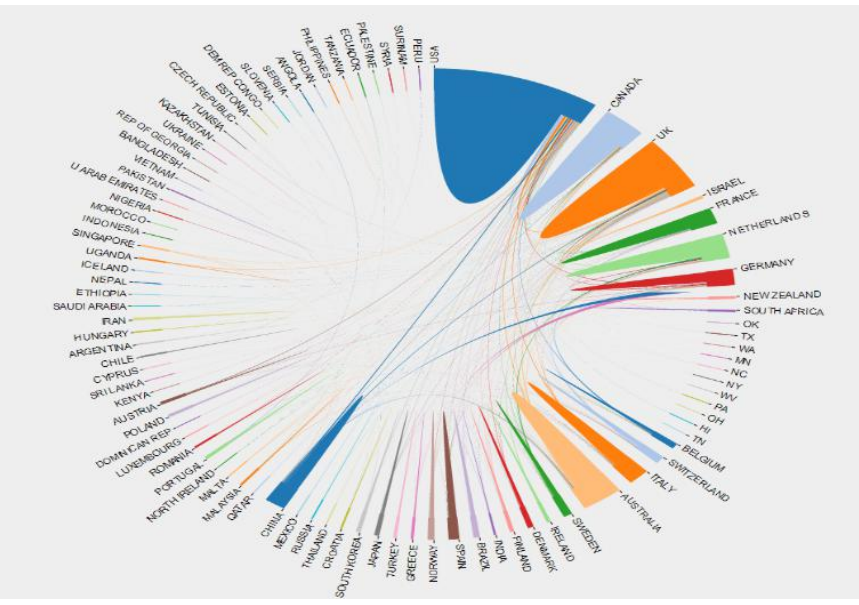

Fig. 5. Interstate literature cooperation

Fig. 6 reflects the cooperation between countries in the field of literature psychoanalysis and academic research. Combined with the results of Fig. 5, we can find that American academic cooperation is extensive, followed by Canada, Britain and Australia. The relationship between the US and China, New Zealand and China is relatively close.

\section{Influence analysis}

The article amount shows the results of the research. The average number of quotes reflects the degree of approval of the peers.

TABLE I. INSTITUTIONAL INFLUENCE

\begin{tabular}{|l|c|c|c|}
\hline \multicolumn{1}{|c|}{ Institutional name } & $\begin{array}{c}\text { Article } \\
\text { amount }\end{array}$ & $\begin{array}{c}\text { Total } \\
\text { number of } \\
\text { quotes }\end{array}$ & $\begin{array}{c}\text { Average } \\
\text { number of } \\
\text { quotes }\end{array}$ \\
\hline Ohio State Univ & 30 & 88 & 2.93 \\
\hline Vrije Univ Amsterdam & 78 & 87 & 1.12 \\
\hline Univ Bergen & 17 & 73 & 4.29 \\
\hline Univ N Carolina & 72 & 71 & 0.99 \\
\hline Harvard Univ & 75 & 57 & 0.76 \\
\hline UCL & 74 & 56 & 0.76 \\
\hline Univ Calif Los Angeles & 56 & 45 & 0.8 \\
\hline Purdue Univ & 10 & 41 & 4.1 \\
\hline Queens Univ & 8 & 39 & 4.88 \\
\hline Univ New S Wales & 54 & 37 & 0.69 \\
\hline Univ Alabama & 22 & 36 & 1.64 \\
\hline Yale Univ & 39 & 35 & 0.9 \\
\hline Duke Univ & 44 & 35 & 0.8 \\
\hline Linkoping Univ & 28 & 35 & 1.25 \\
\hline Karolinska Inst & 36 & 34 & 0.94 \\
\hline Univ Sydney & 66 & 33 & 0.5 \\
\hline Univ Toronto & 126 & 31 & 0.25 \\
\hline Univ Manchester & 68 & 31 & 0.46 \\
\hline Univ Oxford & 42 & 31 & 0.74 \\
\hline Univ Leeds & 32 & 28 & 0.88 \\
\hline
\end{tabular}


From the three aspects of institutions, periodicals and authors, the influential units with both quantity and quality advantages are listed in detail. Results see table I , II and III.

TABLE II. PERIODICAL INFLUENCE

\begin{tabular}{|c|c|c|c|}
\hline Periodical name & \begin{tabular}{|c|} 
Article \\
amount
\end{tabular} & \begin{tabular}{|c|}
$\begin{array}{c}\text { Total } \\
\text { number } \\
\text { of quotes }\end{array}$ \\
\end{tabular} & $\begin{array}{l}\text { Average } \\
\text { number } \\
\text { of quotes }\end{array}$ \\
\hline PSYCHOLOGICAL BULLETIN & 36 & 82 & 2.28 \\
\hline CLINICAL PSYCHOLOGY REVIEW & 40 & 68 & 1.7 \\
\hline PSYCHOLOGICAL METHODS & 15 & 55 & 3.67 \\
\hline 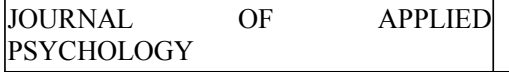 & 14 & 33 & 2.36 \\
\hline \begin{tabular}{|lll} 
JOURNAL & OF & PSYCHOSOMATIC \\
RESEARCH & & \\
\end{tabular} & 21 & 31 & 1.48 \\
\hline PSYCHOSOMATIC MEDICINE & 17 & 31 & 1.82 \\
\hline JOURNAL OF MANAGEMENT & 12 & 30 & 2.5 \\
\hline PSYCHOLOGICAL MEDICINE & 18 & 30 & 1.67 \\
\hline \begin{tabular}{|ll} 
BEHAVIOR & RESEARCH \\
INSTRUMENTS \& COMPUTERS
\end{tabular} & 3 & 29 & 9.67 \\
\hline PAIN & 15 & 27 & 1.8 \\
\hline PSYCHO-ONCOLOGY & 36 & 27 & 0.75 \\
\hline PAIN PHYSICIAN & 10 & 23 & 2.3 \\
\hline $\begin{array}{|lll|}\text { JOURNAL OF ORGANIZATIONAL } \\
\text { BEHAVIOR }\end{array}$ & 14 & 22 & 1.57 \\
\hline HEALTH PSYCHOLOGY & 16 & 20 & 1.25 \\
\hline SOCIAL SCIENCE \& MEDICINE & 43 & 20 & 0.47 \\
\hline CLINICAL JOURNAL OF PAIN & 11 & 19 & 1.73 \\
\hline $\begin{array}{|ll|}\text { JOURNAL OF CONSULTING AND } \\
\text { CLINICAL PSYCHOLOGY }\end{array}$ & 13 & 19 & 1.46 \\
\hline $\begin{array}{|llll|}\begin{array}{l}\text { PSYCHOLOGY } \\
\text { EXERCISE }\end{array} & \text { OF } & \text { SPORT } & \text { AND } \\
\end{array}$ & 15 & 17 & 1.13 \\
\hline JOURNAL OF ADVANCED NURSING & 47 & 16 & 0.34 \\
\hline PLOS ONE & 67 & 16 & 0.24 \\
\hline
\end{tabular}

MacCallum, RC's representative works are "Applications of structural equation modeling in psychological research" and "Evaluating the use of exploratory factor analysis in psychological research".

Cuijpers,P's representative works are A psychoeducational approach to the treatment of depression: A metaanalysis of Lewinsohn's "Coping with Depression" course, Adding Psychotherapy to Pharmacotherapy in the Treatment of Depressive Disorders in Adults: A Meta-Analysis.

TABLE III. AUTHOR INFLUENCE

\begin{tabular}{|l|c|c|c|}
\hline \multicolumn{1}{|c|}{ Author name } & $\begin{array}{c}\text { Article } \\
\text { amount }\end{array}$ & $\begin{array}{c}\text { Total number } \\
\text { of quotes }\end{array}$ & $\begin{array}{c}\text { Average } \\
\text { number of } \\
\text { quotes }\end{array}$ \\
\hline MacCallum, RC & 2 & 52 & 26 \\
\hline Cuijpers, P & 22 & 50 & 2.27 \\
\hline Fabrigar, LR & 1 & 38 & 38 \\
\hline Wegener, DT & 1 & 38 & 38 \\
\hline Strahan, EJ & 1 & 38 & 38 \\
\hline Andersson, G & 11 & 30 & 2.73 \\
\hline Preacher, KJ & 1 & 29 & 29 \\
\hline Hayes, AF & 1 & 29 & 29 \\
\hline van Straten, A & 8 & 28 & 3.5 \\
\hline Bjelland, I & 1 & 24 & 24 \\
\hline Dahl, AA & 1 & 24 & 24 \\
\hline Haug, TT & 1 & 24 & 24 \\
\hline Neckelmann, D & 1 & 24 & 24 \\
\hline
\end{tabular}

\begin{tabular}{|l|c|c|c|}
\hline \multicolumn{4}{|c|}{ Cont. to TABLE III } \\
\hline Hofmann, SG & 6 & 17 & 2.83 \\
\hline Pilling, S & 5 & 16 & 3.2 \\
\hline Hayek, SM & 4 & 16 & 4 \\
\hline Hyde, JS & 5 & 15 & 3 \\
\hline HYDE, JS & 2 & 14 & 7 \\
\hline OLIVER, MB & 1 & 14 & 14 \\
\hline Haythornthwaite, JA & 2 & 14 & 7 \\
\hline
\end{tabular}

Fabrigasr, LR's representative works are evaluating the use of exploratory factor analysis in psychological research.

The keywords obtained through Bibliometric reflect the current research hot spots in the field. Key words with high frequency represent the current academic focus of regular research or specific period.

It shows that the key words of the research object are stress, cancer, nursing, psychological distress and children. The key words that reflect the research means are metaanalysis, systematic review and literature review.

D. Keyword analysis

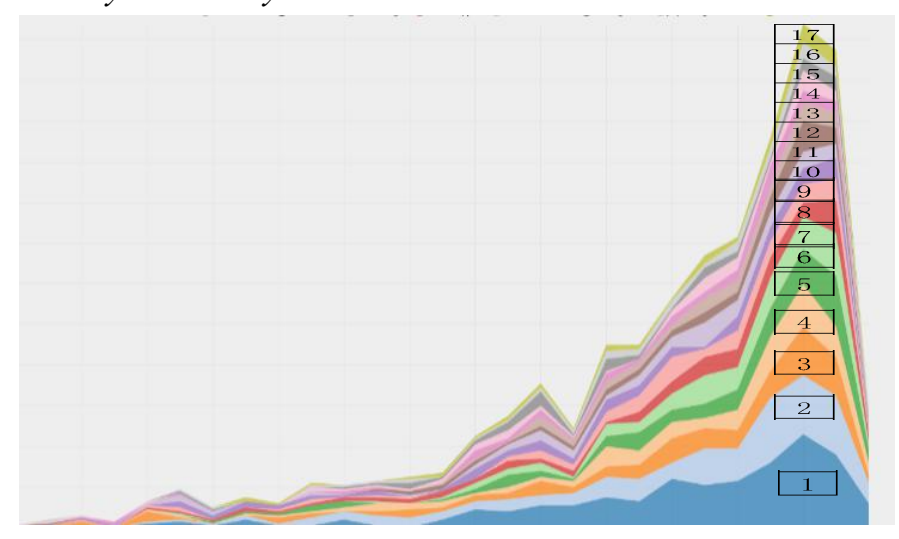

Fig. 6. Keywords

In Fig. 6, the axis of the coordinate axis is time, from 1992 to 2018. The longitudinal axis is the number of documents, the highest number is 248. Keywords are showed in Fig. 7 and numbered. Number 1 represents 'meta-analysis', 2 for 'depression', 3 for 'qualisty of life', 4 for 'anxiety', 5 for 'systematic review', 6 for 'mental health', 7 for'stress', 8 for 'cancer,' and 10 to represent 'cancer,' 10, and 11. 'Scents', 12 for 'well-being', 13 for 'social support', 14 for 'literature review', 15 for 'nursing', 16 for 'psychological distress', 17 for 'children'.

There are several new keywords emerging from the extended keywords. New research objects include women, randomized controlled-trial, and prevalence. Positive psychology interventions include quality of life and social support.

The psychiatry enjoys its importance in institutions and authorities like Ohio State University, Psychological Bulletin, MacCallum, RC. 


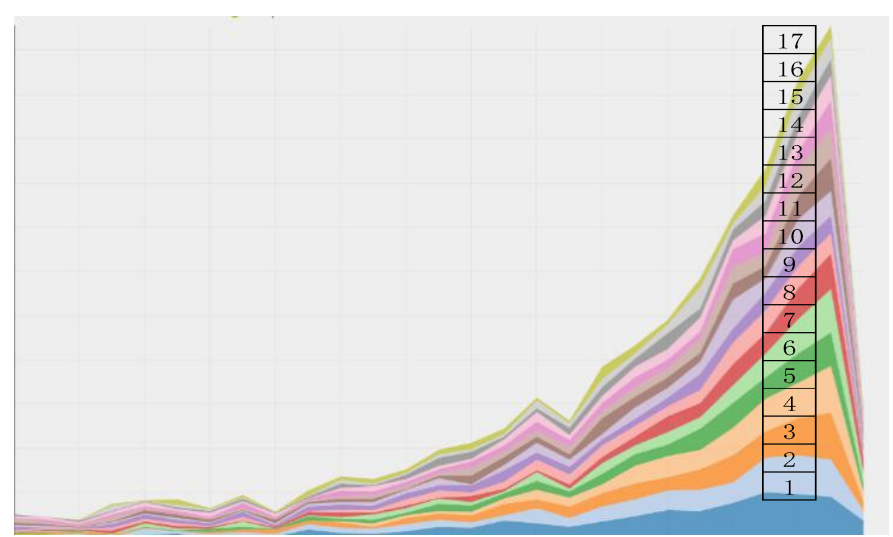

Fig. 7. Extended keywords

Extended keywords are showed in Fig. 7 and numbered. Number 1 represents 'quality of life', 2 for 'depression', 3 for 'health', 4 for 'randomized controlled-trial', 5 for 'psychological distress', 6 for mental health, and 7 for'metaanalysis', 8, and 10. 'Act', 11 for 'model', 12 for 'performance', 13 for 'stress', 14 for 'children', 15 for 'social support', 16 for 'preference', and 17 for 'follow up'.

\section{CONCLUSION}

In view of the current status of literature psychological analysis, this paper uses Bibliometric tools to study the hot spots, influential institutions, periodicals and authors of literary psychological analysis. It is worth noticing that the data obtained from the WOS core database may be incomplete, and the amount of reference may also be affected by erroneous references and malicious references. Based on limited knowledge, the author makes tentative research in order to expand a quantitative research method for related fields. There are several inferences can be made:

The peak year is 2017, the most popular aspect is psychiatry, the most frequent research genre is article, the top research achievements in quantity goes to the US, which owns the most intensive academic cooperation, the Ohio State University comes to the top in influence among institutions. Psychological Bulletin is the leading periodical, MacCallum, $\mathrm{RC}$ is the most being quoted author, the key words of the research object are stress, cancer, and nursing, new research objects include women, randomized controlled-trial, and prevalence. And based on those inferences, three tendencies can be discovered:

In 2017, mental stress among females is the focus of psychological literature especially in the US.

Metal stress and cancer related physical health issues and their counter measurements, as nursing, are the most concerned social problems.

\section{REFERENCES}

[1] Barth, J., et al., "Comparative Efficacy of Seven Psychotherapeutic Interventions for Patients with Depression: A Network Meta-Analysis.' PLOS MEDICINE, 2013. 10.

[2] Schiffman, E., et al., "Diagnostic Criteria for Temporomandibular Disorders (DC/TMD) for Clinical and Research Applications: Recommendations of the International RDC/TMD Consortium Network and Orofacial Pain Special Interest Group.” JOURNAL OF ORAL \& FACIAL PAIN AND HEADACHE, 2014. 28(1): p. 6-27.

[3] Riley, B.D., et al., "Essential Elements of Genetic Cancer Risk Assessment, Counseling, and Testing: Updated Recommendations of the National Society of Genetic Counselors." JOURNAL OF GENETIC COUNSELING, 2012. 21(2): p. 151-161.

[4] McDonald, M.M., C.D. Navarrete and M. Van Vugt, "Evolution and the psychology of intergroup conflict: the male warrior hypothesis." PHILOSOPHICAL TRANSACTIONS OF THE ROYAL SOCIETY BBIOLOGICAL SCIENCES, 2012. 367(1589SI): p. 670-679.

[5] Verweij, K.J.H., et al., "Genetic and environmental influences on cannabis use initiation and problematic use: a meta-analysis of twin studies." ADDICTION, 2010. 105(3): p. 417-430.

[6] Soffietti, R., et al., "Guidelines on management of low-grade gliomas: report of an EFNS-EANO* Task Force.” EUROPEAN JOURNAL OF NEUROLOGY, 2010. 17(9): p. 1124-1133.

[7] Bolier, L., et al., "Positive psychology interventions: a meta-analysis of randomized controlled studies." BMC PUBLIC HEALTH, 2013. 13(119).

[8] Trevena, L.J., et al., "Presenting quantitative information about decision outcomes: a risk communication primer for patient decision aid developers." BMC MEDICAL INFORMATICS AND DECISION MAKING, 2013. 132(S7).

[9] Cuijpers, P., et al., Self-Guided Psychological Treatment for Depressive Symptoms: A Meta-Analysis. PLOS ONE, 2011. 6(e212746).

[10] Dhabhar, F.S., et al., Stress-induced redistribution of immune cells-From barracks to boulevards to battlefields: A tale of three hormones - Curt Richter Award Winner. PSYCHONEUROENDOCRINOLOGY, 2012. 37(9): p. 1345-1368. 